\section{Perioperative changes in superoxide production in neonates and infants}

Katsuya Mikawa MD, Kahoru Nishina MD, Nobuhiro Maekawa MD, Hideaki Yaku MD, Hidefumi Obara MD, Yoshiyuki Uetani MD,* Hajime Nakamura MD*
We conducted a prospective study to investigate perioperative changes in the production of superoxide anion $\left(\mathrm{O}_{2}^{-}\right)$by neutrophils isolated from ten neonates between the ages of five and 16 days ( $N$ group) and ten infants ranging in age from one to ten months (I group). They underwent abdominal surgery under general anaesthesia with halothane and nitrous oxide in oxygen. The $\mathrm{O}_{2}^{-}$production (speed and amount) was measured perioperatively using the cytochrome $c$ reduction method. Both groups showed a decrease in the speed and amount of $\mathrm{O}_{2}^{-}$production during and afier surgery. The decrease in $\mathrm{O}_{2}^{-}$production reached its lowest level three hours postoperatively or at the end of surgery in both groups. The $\mathrm{O}_{2}-$ production in the I group returned to the basal value 48 hr postoperatively. In contrast, the $\mathrm{O}_{2}^{-}$production in the $\mathrm{N}$ group was still lower $48 \mathrm{hr}$ after surgery than before anaesthesia. Although the total amount of $\mathrm{O}_{2}^{-}$production by neutrophils in one $m L$ of peripheral blood remained unchanged in the I group, the total amount of $\mathrm{O}_{2}^{-}$production in the $\mathrm{N}$ group decreased at the end of surgery and thereafter. These data indicate that even relatively minor abdominal surgery with halothane anaesthesia may be associated with perioperative neutrophil impairment in both neonates and infants. This impairment of neutrophil function in infants but not in neonates may be compensated by an increase in neutrophil numbers. It is possible that perioperative susceptibility of neonates to bacterial infections is attributable, at least in part, to the inhibition of $\mathrm{O}_{2}^{-}$production in neutrophils by surgery and general anaesthesia.

Cette étude prospective vise l'évaluation périopératoire des changements de production de l'anion superoxyde $\left(\mathrm{O}_{2}^{-}\right)$par les neutrophiles prélevés chez dix nouveaux-né de 5 à 16 jours

\section{Key words}

ANAESTHESIA: paediatric; IMMUNE RESPONSE: suppression.

From the Departments of Anaesthesiology and *Paediatrics, Kobe University School of Medicine, Kusunoki-cho 7,

Chuo-ku, Kobe 650, Japan.

Address correspondence to: Dr. K. Mikawa.

Accepted for publication 5th August, 1993. (groupe $N$ ) et dix nourrissons de un à dix mois (groupe I). Tous sont soumis à une intervention abdominale sous anesthésie générale à l'halothane et au protoxyde d'azote en oxygène. La production d'O ${ }_{2}^{-}$(vitesse et quantité) est mesurée à la période périopératoire par la méthode de la réduction du cytochrome c. Dans les deux groupes, on décèle une baisse de vitesse et de la quantité dans la production d'O ${ }_{2}^{-}$pendant et après la chirurgie. La production d' $\mathrm{O}_{2}^{-}$atteint dans les deux groupes son niveau le plus bas trois heures après lintervention ou à la fin de lintervention. Dans le groupe I, la production $d^{\prime} \mathrm{O}_{2}^{-}$revient à sa valeur initiale 48 heures après l'opération. Par contre, dans le groupe $\mathrm{N}$, la production $\mathrm{d}^{\prime} \mathrm{O}_{2}^{-}$demeure plus basse 48 heures après la chirurgie qu'avant l'anesthésie. Alors que la quantité totale d'O $\mathrm{O}_{2}^{-}$produite par les neutrophiles dans un $m L$ de sang périphérique demeure inchangée dans le groupe $\mathrm{I}$, la quantité totale $\mathrm{d}^{\prime} \mathrm{O}_{2}^{-}$produite dans le groupe $N$ diminue à la fin de la chirurgie et par la suite. Ces données montrent que même une chirurgie abdominale mineure avec anesthésie à l'halothane peut être associée à une atteinte périopératoire tant chez le nouveau-né que chez le nourrisson. Cette atteinte de la fonction des neutrophiles chez le nourisson peut être compensée par l'augmentation du nombre de neutrophiles. Il est possible, d'autre part, que la susceptibilité périopératoire des nouveaux-nés aux infections bactériennes soit attribuable, partiellement du moins, à l'inhibition de la production d'O ${ }_{2}^{-}$ dans les neutrophiles pendant la chirurgie générale et l'anesthésie.

Production of one of the reactive oxygen species from neutrophils, superoxide anion $\left(\mathrm{O}_{2}^{-}\right)$, has been compared to a double-edged sword. Release of $\mathrm{O}_{2}^{-}$plays a crucial role in the host defence system against bacterial infection as a component of nonspecific cell mediated immunity. ${ }^{1,2}$ However, numerous studies have indicated that inadvertent excessive release of $\mathrm{O}_{2}{ }^{-}$from neutrophils into the surrounding milieu results in inflammatory auto-injury and is associated with respiratory failure. ${ }^{3,4}$

It is well established that both anaesthesia and surgery cause transient immunosuppression. ${ }^{5-7}$ This suppressive effect is apparent within 10-15 min of induction of anaesthesia ${ }^{5}$ and is greatest during the immediate postopera- 
TABLE I Demographic data of patients studied. Values are expressed as mean \pm SEM

\begin{tabular}{lll}
\hline Characteristics & $\begin{array}{l}\text { Neonates } \\
(\text { N group })\end{array}$ & $\begin{array}{l}\text { Infants } \\
\text { (Igroup) }\end{array}$ \\
\hline Number of patients & 10 & 10 \\
Sex (male:female) & $8: 2$ & $7: 3$ \\
Age (d) & $9.1 \pm 1.2$ & \\
(mo) & $38 \pm 0.2$ & $5.3 \pm 0.8$ \\
Gestational age (wk) & $2.9 \pm 0.1$ & $39 \pm 0.2$ \\
Weight (kg) & $2.0 \pm 0.2$ & $2.4 \pm 0.4$ \\
Duration of anaesthesia (hr) & $1.1 \pm 0.1$ & $1.9 \pm 0.2$ \\
Duration of operation (hr) & & \\
\hline
\end{tabular}

tive period. ${ }^{6}$ Nakagawara et al. reported that inhalation anaesthetics inhibited $\mathrm{O}_{2}{ }^{-}$production by impairing the mobilization of intracellular calcium. ${ }^{8}$ We hypothesise that, even in neonates and infants, $\mathrm{O}_{2}^{-}$generation by neutrophils decreases during and after surgery, possibly leading to postoperative infection.

On the other hand, major surgery in adults, such as resection of tissue for oesophageal or liver cancer, is thought to lead to host auto-injury (e.g., acute lung injury) by increasing $\mathrm{O}_{2}-$ production which amplifies the inflammatory response. In neonates and infants, we previously observed increases in plasma activated complements (C3a and C5a) after abdominal surgery., ${ }^{9,10}$ These chemical mediators have ability to activate neutrophils, leading to release of $\mathrm{O}_{2}{ }^{-} .{ }^{4}$ Thus, a possibility exists that, after abdominal surgery for the two populations, the perioperative increased $\mathrm{O}_{2}^{-}$production by neutrophils may be high enough to cause respiratory failure.

To test these two conflicting hypotheses, we examined whether $\mathrm{O}_{2}^{-}$production changed perioperatively in neonates and infants undergoing abdominal surgery, and further whether there was a difference between neonates and infants in the pattern of the perioperative changes, if they existed. Despite their possible importance as a clinical observation, perioperative changes in $\mathrm{O}_{2}{ }^{-}$production in neonates and infants have not been reported.

\section{Results}

\section{Subjects}

This study was conducted after institutional approval and informed consent from the parents of all patients. Previous experiments of $\mathrm{O}_{2}$ - production required large quantities of blood, so that the studies were not feasible until it became possible to measure $\mathrm{O}_{2}{ }^{-}$production in a small amount of blood by using improved equipment. This consists of a double-beam spectrophotometer and a data analysis system with a microcomputer for eliminating the noise (background) caused by the cells during measurement. ${ }^{11,12}$
TABLE II Operations performed in the current study

\begin{tabular}{|c|c|c|}
\hline Operations & $\begin{array}{l}\text { Neonates } \\
\text { (N group) }\end{array}$ & $\begin{array}{l}\text { Infants } \\
\text { (I group) }\end{array}$ \\
\hline Gastrostomy & 5 & I \\
\hline \multicolumn{3}{|l|}{ Pyloromyotomy } \\
\hline (Ramstedt's operation) & 5 & 0 \\
\hline Repair of intestinal stoma & & 1 \\
\hline Inguinal hernia repair & & 3 \\
\hline \multicolumn{3}{|c|}{ Operation for Hirshsprung's disease } \\
\hline (Soave's procedure) & & 2 \\
\hline Repair of imperforate anus & - & $\underline{3}$ \\
\hline Total & 10 & 10 \\
\hline
\end{tabular}

We studied the $\mathrm{O}_{2}{ }^{-}$production by neutrophils in ten neonates ( $\mathrm{N}$ group) between the ages of five and 16 days, and in ten infants (I group) ranging in age from one to ten months who were ASA physical status I or II. The following patients were excluded from the trial: premature neonates, patients with hyperbilirubinaemia, or clinical immune, renal, or hepatic disease, patients with malignant disease or infection, and those who had received steroids or immunosuppressive agents. Table I indicates the general data on the two groups. All patients underwent abdominal surgery (Table II).

\section{Anaesthetic management}

All neonates and some infants underwent preoperative fluid therapy to attain a suitable condition for surgery. The infants who did not receive preoperative fluid therapy were allowed to ingest up to $10 \mathrm{ml} \cdot \mathrm{kg}^{-1}$ of clear fluids three hours before the scheduled surgery. None of the patients was premedicated. Gastric contents in all neonates were aspirated preoperatively. In all patients, anaesthesia was induced with halothane (up to $2.5 \%$ inspired) and maintained with halothane $0.5-1.5 \%$ and $50-60 \%$ nitrous oxide $\left(\mathrm{N}_{2} \mathrm{O}\right)$ in oxygen. Induction of anaesthesia in all patients was started at 8:30 a.m. Muscle relaxation was obtained with vecuronium with which tracheal intubation was facilitated. Holl described that tracheal intubation may be achieved by either rapid-sequence, awake, or inhalation technique for neonates with pyloric stenosis. ${ }^{13}$ MacDonald et al. demonstrated that mask inhalation induction preceded by careful emptying of the stomach has been used safely in several paediatric centres. ${ }^{14}$ In our hospital, patients with pyloric stenosis were prepared carefully before surgery by correcting hypovolaemia and abnormalities in blood electrolytes concentrations and by continuously aspirating gastric contents. Thus, inhalational induction is frequently used for these patients without regurgitation and none was malnourished.

Catecholamines, adrenergic agonists or antagonists, or calcium channel blockers, were not administered 
throughout the study. Ventilation was controlled to maintain $\mathrm{PaO}_{2}$ at more than $19 \mathrm{kPa}(143 \mathrm{mmHg})$ and the $\mathrm{PaCO}_{2}$ within $4.2-6.0 \mathrm{kPa}(31.5-45 \mathrm{mmHg})$. In all patients, the trachea was extubated in the operating room following surgery after residual neuromuscular blockade had been reversed with neostigmine $0.05 \mathrm{mg} \cdot \mathrm{kg}^{-1}$ and atropine $0.02 \mathrm{mg} \cdot \mathrm{kg}^{-1}$, and patients were then transferred to the intensive care unit (ICU). Using a rectal or oesophageal probe, body temperature was maintained between $37.1-37.7^{\circ} \mathrm{C}$ during and after surgery to avoid stress from hypo- or hyperthermia. The patients received an $i v$ solution ( $\mathrm{Na} 20-45 \mathrm{mEq}, \mathrm{Cl} 20-35 \mathrm{mEq}, \mathrm{K}$ 0-17.5 $\mathrm{mEq}$, and $2.5-5 \%$ glucose in a $500 \mathrm{ml}$ solution) at a rate of $7-12 \mathrm{ml} \cdot \mathrm{kg}^{-1} \cdot \mathrm{hr}^{-1}$ intraoperatively and $80-140$ $\mathrm{ml} \cdot \mathrm{kg}^{-1} \cdot$ day $^{-1}$ postoperatively. This regimen is routine in our clinical setting. ${ }^{9,10,15,16}$ All patients were deprived of food until completion of the last blood sampling. No patients received blood transfusion. Five infants undergoing surgery for Hirshsprung's disease or imperforate anus received $5 \%$ albumin intraoperatively to replace blood loss. Although albumin has been shown to affect $\mathrm{O}_{2}{ }^{-}$production by phagocytes in in vitro experiments, ${ }^{17}$ whether or not albumin administered to infants has effect on the $\mathrm{O}_{2}^{-}$production in vivo is unknown. The mean urine output in all patients was $>0.6 \mathrm{ml} \cdot \mathrm{kg}^{-1} \cdot \mathrm{hr}^{-1} \mathrm{dur}$ ing and after surgery. This volume was accepted as within standard values in paediatric anaesthesia and perioperative blood concentrations of potassium, sodium, and chloride were within normal ranges, suggesting that the rate and composition of the infusion were appropriate. None of the patients received analgesics postoperatively and clinical evidence of postoperative wound infection was found in only one neonate undergoing gastrostomy. Blood pressure (BP), which was monitored through a radial arterial catheter and/or by using an automated oscillotonometer, was stable within normal physiological ranges (systolic BP: $56-108 \mathrm{mmHg}(7.5-14 \mathrm{kPa}$ ) and diastolic BP: $34-77 \mathrm{mmHg}(4.5-10 \mathrm{kPa})$ ) during the study period. Heart rate, continuously monitored by ECG (lead II), was maintained between 93 and 172 beats $\cdot \mathrm{min}^{-1}$ throughout the study. No ventricular arrhythmias were observed. The results of postoperative arterial blood gas analyses were also consistently within normal ranges at each point of sample collection. No patients vomited during the induction of anaesthesia, or after anaesthesia.

\section{$\mathrm{O}_{2}-$ generation analysis}

\section{REAGENTS}

Cytochrome $c$ type VI, N-formyl-methionyl-leucylphenylalanine (FMLP), and phorbol myristate acetate (PMA) were obtained from Sigma Chemical Co. (St.
Louis, MO). Phosphate-buffered saline containing $\mathrm{Ca}^{++}$ and $\mathrm{Mg}^{++}$(PBS) was obtained from Nakarai Chemical Co. (Kyoto, Japan).

\section{SAMPLE COLLECTION}

Under local anaesthesia, before the induction of general anaesthesia, a radial arterial catheter was inserted both to sample blood and to measure the arterial pressure continuously. One milliliter of heparinized blood was drawn before anaesthesia (basal value), during surgery (about halfway through the operative procedure), at the completion of anaesthesia, and 3,6,24, and $48 \mathrm{hr}$ after the completion of anaesthesia. The $\mathrm{O}_{2}^{-}$production was then determined using the improved measuring apparatus and the number of neutrophils in the peripheral blood was also determined with a Coulter Counter ${ }^{\circledR}$ STKS (Coulter Electronics, Harkenden, England), leukocyte subpopulation analyzer.

\section{ISOLATION OF NEUTROPHILS}

Neutrophils were isolated by means of dextran sedimentation, centrifugation through Lymphoprep ${ }^{\circledR}$ (Nycomed, AS, Oslo, Norway) followed by the hypotonic lysis of erythrocytes. Isolated neutrophils were resuspended in PBS consisting of $10 \mathrm{nM}$ phosphate (pH 7.4), $137 \mathrm{mM}$ $\mathrm{NaCl}$, and $2.7 \mathrm{mM} \mathrm{KCl}$. They were then diluted to a concentration of $5 \times 10^{6}$ cells $\cdot \mathrm{ml}^{-1}$. The cell analysis showed that more than $98 \%$ of the cells were neutrophils, and the trypan blue dye exclusion test confirmed that $>98 \%$ of the cells were viable.

\section{MEASUREMENT OF $\mathrm{O}_{2}^{-}$PRODUCTION}

The spectrophotometric measurement of $\mathrm{O}_{2}{ }^{-}$-dependent cytochrome $c$ reduction was performed by a double-beam spectrophotometer. The spectrophotometer had differential circuits of 550 and $540 \mathrm{~nm}$ and was equipped with a thermoregulator which was set at $37^{\circ} \mathrm{C}$ (model SA1, Arrows, Osaka, Japan) as described previously. ${ }^{11,12}$ The cuvette contained $20 \mu \mathrm{M}$ ferricytochrome $c, 1 \times 10^{5}$ neutrophils and $5 \mathrm{mM}$ glucose in $1 \mathrm{~mL}$ of PBS at pH 7.4. Neutrophils were stimulated by either FMLP ( $4 \mathrm{nM}$ at final concentration), chemotactic peptide, or PMA (0.1 $\mu \mathrm{g} \cdot \mathrm{ml}^{-1}$ at final concentration), protein kinase $\mathrm{C}$ activator. The rate of cytochrome $c$ reduction was measured by the change in absorbance at 550-540 nm. When PMA was used as a stimulant, a linear change in the absorbance was observed between two-four minutes after the addition of the agent and the absorbance continued to increase, at a lower rate, for over ten minutes. When FMLP was used as a stimulant, the absorbance reached a plateau three minutes after the addition of the agent. Thus, the speed of $\mathrm{O}_{2}^{-}$production by PMA stimulation was calculated from the linear slope of cytochrome $c$ reduction 
while the integration (amount) of PMA-induced $\mathrm{O}_{2}{ }^{-}$production was ciphered from the value of time-absorbance curve at $15 \mathrm{~min}$ post-PMA stimulation point, from which the curve was almost flat. The speed and amount (integration) of $\mathrm{O}_{2}^{-}$production by FMLP was calculated from the increase in the cytochrome $c$ reduction between 30 and $90 \mathrm{sec}$ and the amount of cytochrome $c$ reduced for three minutes after FMLP stimulation, respectively. A value of 19.1 was used for the absorbance coefficient of cytochrome $c$ at $\mathrm{OD}_{550-540}$.

\section{SENSITIVITY, SPECIFICITY, AND VARIABILITY OF THE ASSAY} SYSTEM

The lower limit of sensitivity of this assay system is approximately $0.005 \mathrm{nmol} \cdot \mathrm{min}^{-1}$. This amount of $\mathrm{O}_{2}{ }^{-}$production is usually obtained by $500-1000$ normal neutrophils. Specificity of the assay system is $99.5 \%$. Intra- and inter-assay coefficients of variance are $8.6 \%$ and $9.2 \%$, respectively.

\section{Analysis of $\mathrm{O}_{2}^{-}$Induced Auto-Injury}

Acute lung injury (assessed by $\mathrm{PaO}_{2} / \mathrm{FrO}_{2}$ ratio) was adopted as an indicator of $\mathrm{O}_{2}{ }^{-}$induced auto-injury. To examine the relationship between $\mathrm{PaO}_{2} / \mathrm{FIO}_{2}$ ratio and the total amount of $\mathrm{O}_{2}{ }^{-}$production (stimulated by FMLP or PMA) within the groups, scatterplots, least squares line, and correlation coefficient were derived.

\section{Statistics}

Linear regression analysis was performed on the data using a packaged statistical software program (Statview II, Abacus Concepts, CA). Significance of differences was evaluated by analysis of variance with repeated measures and $t$ test (paired and unpaired). A $P$ value of $<0.05$ was deemed significant.

In the current study, the small number of patients ( $n$ $=10$ ) was likely to increase the probability of type II error $(\beta=0.2)$. However, even this number was sufficient to detect great difference (significance difference $\mid \mu \mathrm{A}-$ $\mu \mathrm{B} \mid / \sigma=1.0-1.4)$, if existed, in mean $\mathrm{O}_{2}{ }^{-}$production compared with basal values within groups. The sample size $(n)$ required to provide a significant difference was calculated according to the following formula: ${ }^{18,19}$

$$
\begin{aligned}
n & =\left(\mathrm{Z}_{1-\beta}+\mathrm{Z}_{1-\alpha / 2}\right)^{2} \times\left(\sigma \mathrm{A}^{2}+\sigma \mathrm{B}^{2}\right) /|\mu \mathrm{A}-\mu \mathrm{B}|^{2} \\
& =7.84 \times\left(\sigma \mathrm{A}^{2}+\sigma \mathrm{B}^{2}\right) / \mu \mathrm{A}-\left.\mu \mathrm{B}\right|^{2} \\
& =15.68 \times \sigma^{2} /|\mu \mathrm{A}-\mu \mathrm{B}|^{2}
\end{aligned}
$$

Where $1-\beta=0.8$ (power), $\alpha=0.05$ (significance level of two-sided alternative), $(\mu \mathrm{A}-\mu \mathrm{B})=$ differences in means, and $\sigma=$ standard deviations (provided that $\sigma \mathrm{A}$ $=\sigma \mathrm{B}$ ). Some patterns where $n$ was approximately 10 or less met the above formula.

\section{Results}

As shown in Figure 1, the speed and amount (integration) of $\mathrm{O}_{2}{ }^{-}$production in the $\mathrm{N}$ group, which were stimulated by FMLP or PMA, were within normal ranges before anaesthesia was started. This was consistent with our previous reports. ${ }^{11,12}$ The $\mathrm{O}_{2}^{-}$production (speed and amount) in the $\mathrm{N}$ and I groups, however, began to decrease during surgery (Figures 1 and 2). In the $\mathrm{N}$ group, the variables decreased extensively during surgery and were minimal three hours postoperatively with a return towards the basal value apparent $48 \mathrm{hr}$ after surgery but still remained low. In contrast, the speed and amount of $\mathrm{O}_{2}{ }^{-}$production in the I group was minimal three hours postoperatively or at the end of surgery and returned to basal value $48 \mathrm{hr}$ postoperatively (Figure 2). The neutrophil counts in the peripheral blood showed a slight increase during the course of surgery in both groups and seemed to be at peak three hours after surgery (Figures 1 and 2).

The average maximum decrease in $\mathrm{O}_{2}^{-}$production. In the $\mathrm{N}$ group, $65-70 \%$ changes in the speed and amount of $\mathrm{O}_{2}-$ production were observed, as opposed to $29-41 \%$ changes for the I group (Table III).

To assess whether or not the decrease in the amount (integration) of $\mathrm{O}_{2}^{-}$production (per $10^{6}$ neutrophils) could be compensated by an increased number of neutrophils in the peripheral blood, we computed the ability of neutrophils in one $\mathrm{mL}$ of peripheral whole blood to generate $\mathrm{O}_{2}-$ by multiplying the value of the FMLPor PMA-induced amount (integration) of $\mathrm{O}_{2}^{-}$production per $10^{6}$ isolated neutrophils by the neutrophil counts in the peripheral blood. The ability of the neutrophils in one $\mathrm{mL}$ of peripheral blood to produce $\mathrm{O}_{2}-$ postoperatively decreased in the $\mathrm{N}$ group but remained unchanged in the I group (Figures 3 and 4). When PMA was used as a stimulant, the ability to produce $\mathrm{O}_{2}^{-}$also decreased after surgery in the $\mathbf{N}$ group as well (Figure 3). In contrast, the ability in the I group postoperatively increased rather than being unchanged (Figure 4).

No correlation between $\mathrm{PaO}_{2} / \mathrm{FIO}_{2}$ ratio and the total amount of $\mathrm{O}_{2}{ }^{-}$production was observed in neonates or infants (data not shown).

\section{Discussion}

Several lines of evidence in literature indicate that the immunosuppressive effects of both anaesthesia and surgery are apparent within 10-15 min of induction of anaesthesia ${ }^{5}$ and are greatest during the immediate postoperative period. ${ }^{6}$ In the current study, depression of $\mathrm{O}_{2}-$ production by neutrophils was observed in neonates and infants undergoing abdominal surgery under general anaesthesia with halothane and $\mathrm{N}_{2} \mathrm{O}$. This observation is consistent with previous reports, which claimed that 


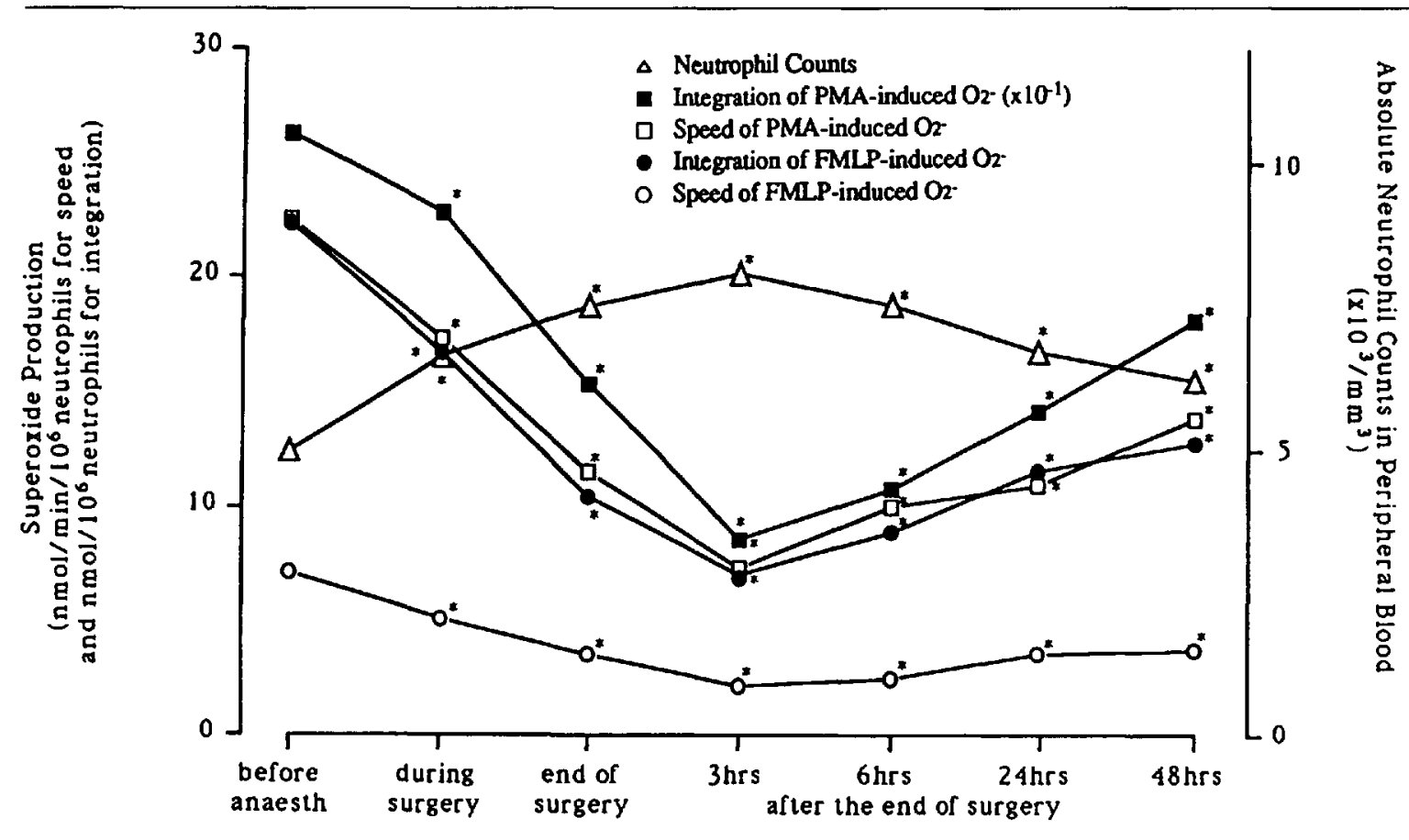

Samples

FIGURE I Perioperative changes in $\mathrm{O}_{2}^{-}$production stimulated by PMA $\left(0.1 \mu \mathrm{g} \cdot \mathrm{ml}^{-1}\right)$ or FMLP $(4 \mathrm{n} M)$ and neutrophil counts in peripheral blood in neonates. Values are expressed as mean \pm SEM. PMA: phrobol myristate acetate, FMLP: N-formyl-methionyl-leucyl-phenylalanine. ${ }^{*} P<$ 0.05 vs basal value within group.

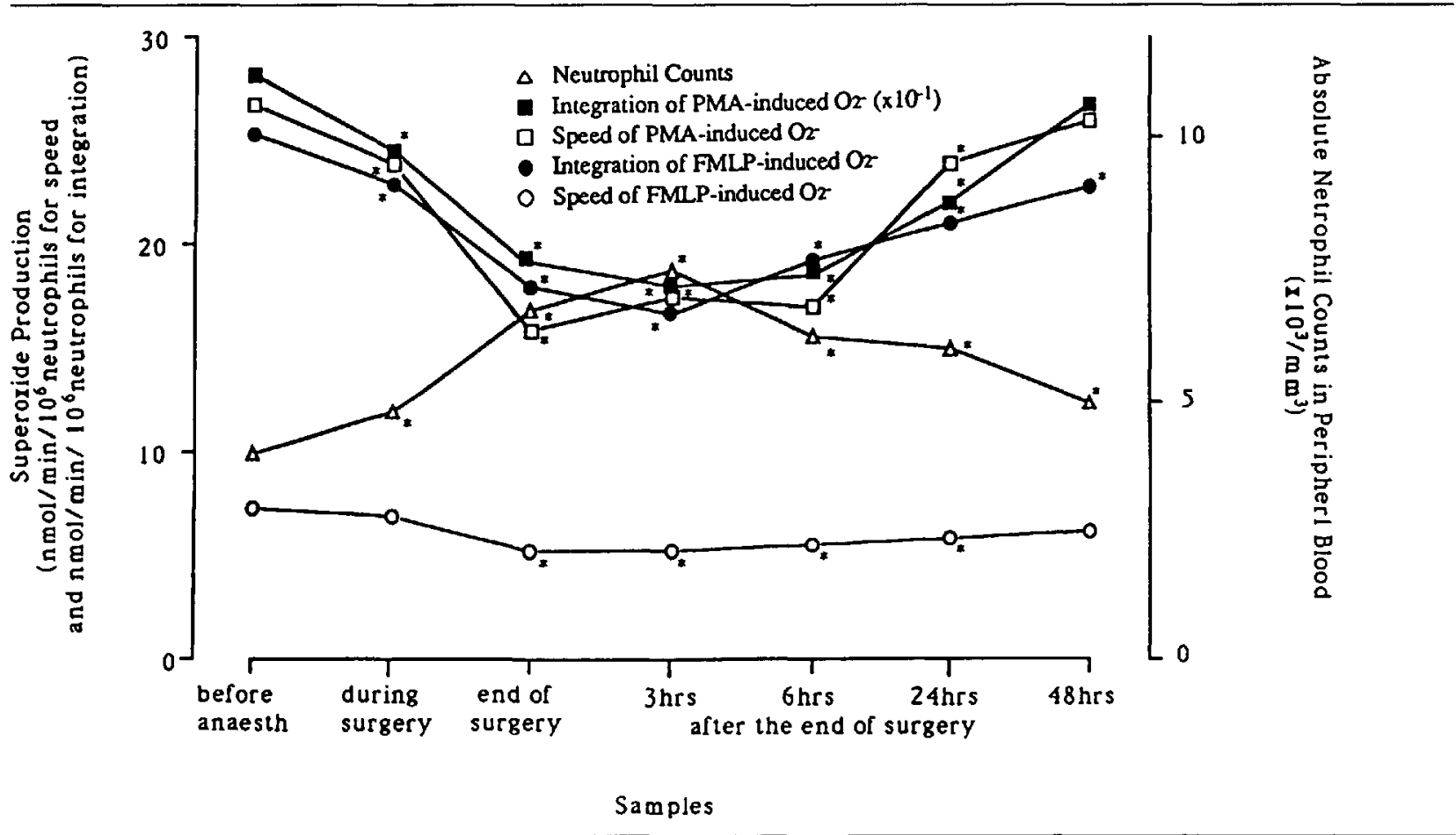

FIGURE 2 Perioperative changes in $\mathrm{O}_{2}^{-}$production stimulated by PMA $\left(0.1 \mu \mathrm{g} \cdot \mathrm{ml}^{-1}\right)$ or FMLP $(4 \mathrm{n} M)$ and neutrophil counts in peripheral blood in infants. Values are expressed as mean \pm SEM. PMA: phorbol myristate acetate, FMLP: N-formyl-methionyl-leucyl-phenylalanine. ${ }^{*} P<$ 0.05 s basal value within group. 
TABLE III Maximum changes (mean \pm SEM) in $\mathrm{O}_{2}^{-}$production induced by FMLP or PMA in neonates and infants

\begin{tabular}{|c|c|c|c|c|}
\hline & \multicolumn{2}{|c|}{ Neonates ( $N$ group) } & \multicolumn{2}{|c|}{ Infants (I group) } \\
\hline & $F M L P$ & $P M A$ & $F M L P$ & $P M A$ \\
\hline \multicolumn{5}{|c|}{ Speed of $\mathrm{O}_{2}^{-}$production ( $\mathrm{nmol} \cdot \mathrm{min} \cdot 10^{-6}$ neutrophils) } \\
\hline - Basal value (before anaesthesia) & $7.0 \pm 0.9$ & $22.9 \pm 1.6$ & $7.3 \pm 1.1$ & $26.8 \pm 1.3$ \\
\hline - Minimum value & $2.4 \pm 0.5$ & $7.3 \pm 0.8$ & $5.2 \pm 0.8$ & $15.8 \pm 1.2$ \\
\hline - Percent change (\%) & $65 \pm 4$ & $68 \pm 3$ & $29 \pm 3$ & $41 \pm 5$ \\
\hline \multicolumn{5}{|c|}{ Integration of $\mathrm{O}_{2}^{-}$production (nmol $\cdot 10^{-6}$ neutrophils) } \\
\hline - Basal value (before anaesthesia) & $22.8 \pm 1.7$ & $268 \pm 15$ & $25.6 \pm 1.2$ & $281 \pm 16$ \\
\hline - Minimum value & $7.0 \pm 0.8$ & $81 \pm 8$ & $16.1 \pm 1.2$ & $181 \pm 13$ \\
\hline - Percent change $(\%)$ & $69 \pm 4$ & $70 \pm 6$ & $37 \pm 4$ & $36 \pm 6$ \\
\hline
\end{tabular}

FMLP: N-formyl-methionyl-leucyl-phenylalanine, PMA: phorbol myristate acetate.

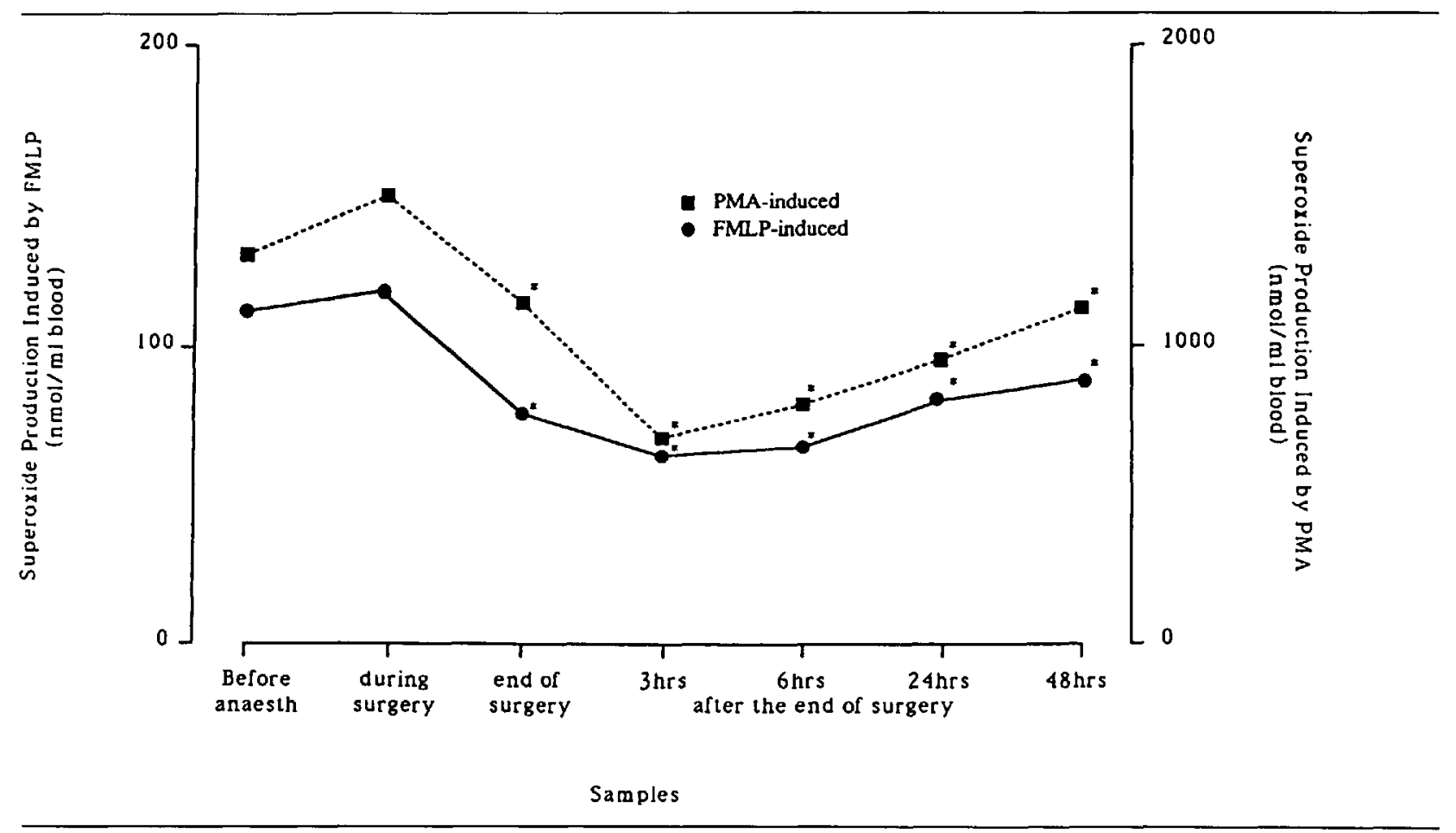

FIGURE 3 Perioperative changes in total $\mathrm{O}_{2}^{-}$production stimulated by PMA $\left(0.1 \mu \mathrm{g} \cdot \mathrm{ml}^{-1}\right)$ or FMLP $(4 \mathrm{nM})$ in neonates. Values are expressed as mean \pm SEM. PMA: phrobol myristate acetate, FMLP: $N$-formyl-methionyl-leucyl-phenylalanine. ${ }^{*} P<0.05$ vs basal value within group.

anaesthesia and surgery had immunosuppressive effects including impairment of neutrophil microbicidal activity. However, as indicated by the total amount of $\mathrm{O}_{2}^{-}$production by neutrophils in one $\mathrm{mL}$ of peripheral blood (Figure 3 and 4 ), the decrease in $\mathrm{O}_{2}{ }^{-}$production per unit of neutrophil could be compensated by an increased number of neutrophils in the peripheral blood in the $\mathrm{I}$ group. In contrast, the total amount of $\mathrm{O}_{2}{ }^{-}$production in the peripheral blood in the $\mathrm{N}$ group remained low during and after surgery. The durations of anaesthesia and surgery were longer in the $\mathrm{I}$ group than in the $\mathrm{N}$ group (Table I). Thus, we may conclude that, despite a more prolonged anaesthetic and surgical time, infants tolerated anaesthesia with less depression of the $\mathrm{O}_{2}-$ production than did neonates. These results may partly explain why neonates are susceptible to bacterial infection after surgery and why the incidence of postoperative infection is higher in neonates than in infants.

Neutrophils generate $\mathrm{O}_{2}-$ during phagocytosis or when stimulated by various types of agents. ${ }^{20,21}$ Figure 5 il- 


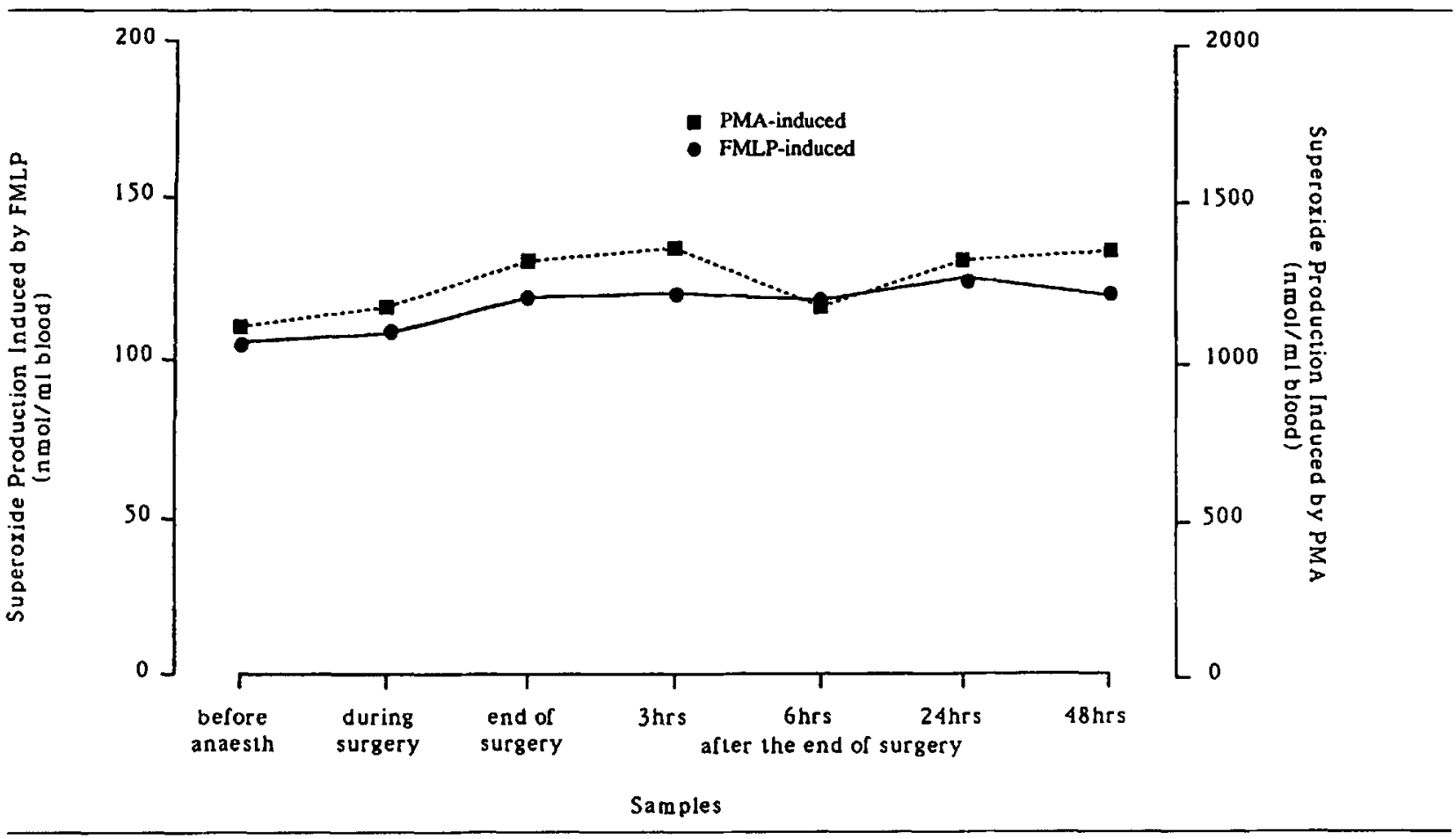

FIGURE 4 Perioperative changes in total $\mathrm{O}_{2}^{-}$production stimulated by PMA $\left(0.1 \mu \mathrm{g} \cdot \mathrm{ml}^{-1}\right)$ or FMLP $(4 \mathrm{nM})$ in infants. Values are expressed as mean \pm SEM. PMA: phorbol myristate acetate, FMLP: N-formyl-methionyl-leucyl-phenylalanine. ${ }^{*} P<0.05$ vs basal value within group.

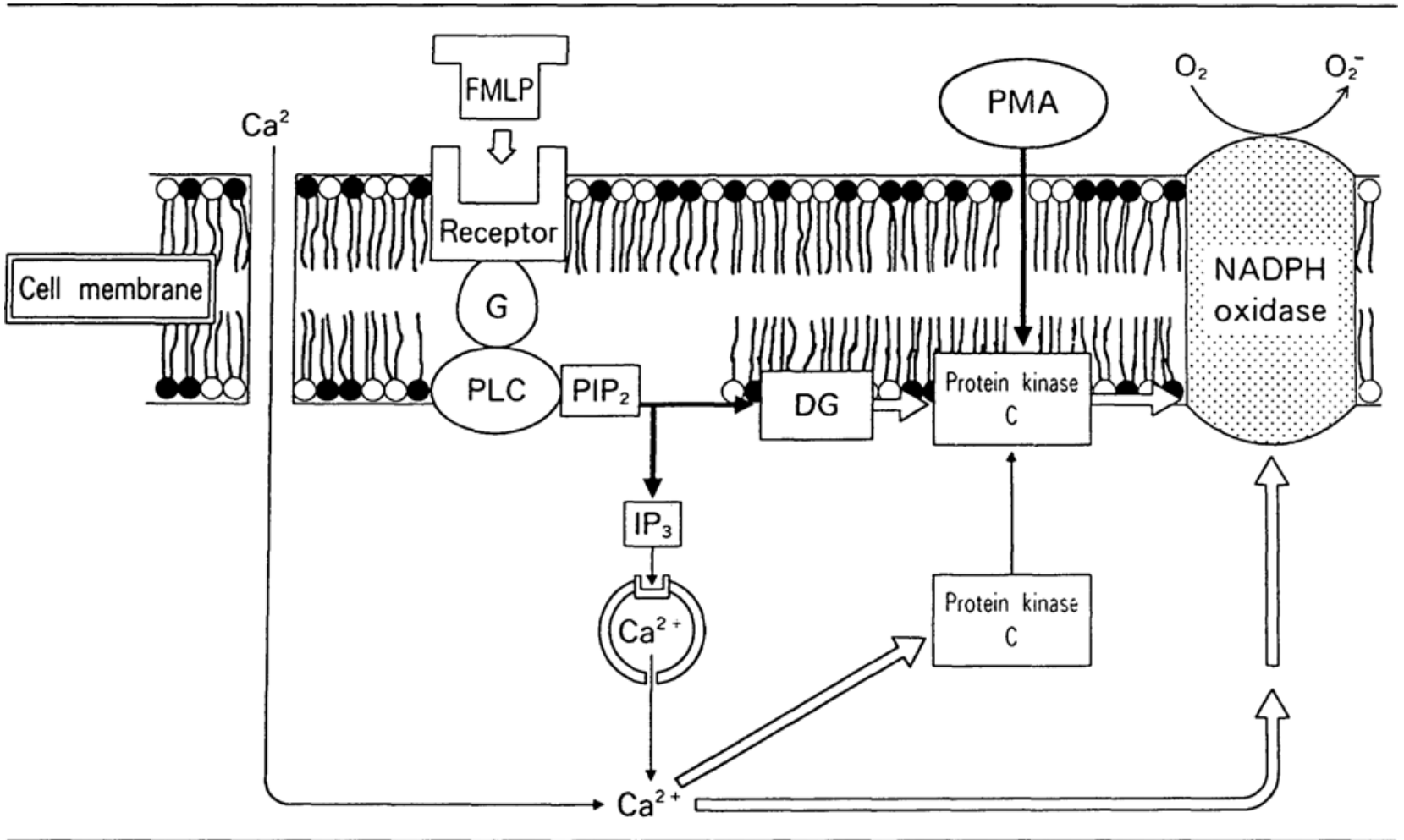

FIGURE 5 Schematic diagram of the mechanism of NADPH-dependent $\mathrm{O}_{2}{ }^{-}$production and possible target of inhibiton. DG: diacylglycerol, G: guanosine triphosphate (GTP)-binding protein, PLC: phospholipase C, $\mathrm{PIP}_{2}$ : phosphatidylinositol bisphosphate, $\mathrm{IP}_{3}$ : inositol triphosphate. 
lustrates the currently accepted mechanism of NADPHdependent $\mathrm{O}_{2}{ }^{-}$production: ${ }^{21,22}$ NADPH oxidase, which is present in the cell membrane of neutrophils, is thought to be the enzyme that produces $\mathrm{O}_{2}{ }^{-}$. There are three pathways by which extracellular stimuli are transmitted to activate NADPH oxidase. They are mediated by: (1) inositol triphosphate when FMLP is used as a stimulant, (2) protein kinase $\mathrm{C}$ when PMA is used as a stimulant, and (3) calcium ionophore. Nakagawara et al. reported that halothane inhibited $\mathrm{O}_{2}{ }^{-}$production by impairing the mobilization of intracellular calcium. ${ }^{8}$ Furthermore, catecholamines, such as dopamine ${ }^{22}$ and isoproterenol, ${ }^{23} \mathrm{re}-$ portedly reduce $\mathrm{O}_{2}^{-}$production. It is likely that multiple perioperative factors in the current study are involved with the perioperative inhibition of $\mathrm{O}_{2}^{-}$production. These factors include surgical stress, anaesthetics, hormonal response, prostaglandins, chemical mediators, cytokines, and postoperative pain, all of which can modulate immune system activity including neutrophil response. ${ }^{24-28}$ The precise extent of surgical stress in the current study, which is one of the most influential factors in immunodepression, is unknown because plamsa concentrations of hormones released during stress such as catecholamines and cortisol were not determined. However, the degree of surgical stress was thought to be greater in the I group than in the $\mathbf{N}$ group according to the type of surgery, and duration of surgery and anaesthesia. It is noteworthy that $\mathrm{O}_{2}-$ production was inhibited to a greater extent and for a longer time in the $\mathrm{N}$ group despite the relatively minor abdominal surgical procedures in this group. Compared with minor abdominal surgery, thoracic and cardiovascular surgery with the added stress of long duration in neonates may cause more prolonged and greater inhibition of $\mathrm{O}_{2}^{-}$production, which may lead to serious infection. At the present time, however, we are unable to elucidate the precise mechanism of the inhibition of $\mathrm{O}_{2}{ }^{-}$production and the difference in the magnitude of the decrease in $\mathrm{O}_{2}^{-}$production between the two groups.

It is well known that neonates have an immature (cellular and humoral) immune system. ${ }^{29}$ This includes several functional defects in neutrophils from human neonates, such as adherence, aggregation, movement, and phagocytosis. ${ }^{30}$ There may be developmental defects in signal transduction, cell surface receptor upregulation and mobility, cytoskeletal rigidity, microfilament contraction, and oxygen metabolism. Although the precise age at which most of these immune functions reach maturity is unknown, they may be mature by two to three months of age. ${ }^{29}$ Although our data show that the basal (preoperative) ability of $\mathrm{O}_{2}^{-}$production in neonates was comparable with that in infants, the ability of perioperative $\mathrm{O}_{2}-$ production seemed to be lower in neonates than in infants despite the possibly greater surgical stress in the latter. This may be due to immaturity of neutrophils in neonates. The finding may also explain previous reports ${ }^{31,32}$ in which neonates are perioperatively susceptible to bacterial infection.

In the current study, only one neonate contracted an infection despite the decrease in $\mathrm{O}_{2}{ }^{-}$production. The sample size was too small to derive any clinical implication of the perioperative decrease in $\mathrm{O}_{2}^{-}$production. A larger sample size may have led us to conclude that decreased perioperative $\mathrm{O}_{2}{ }^{-}$production causes postoperative susceptibility of neonates to bacterial infections.

In conclusion, we have shown that relatively minor abdominal surgery caused a perioperative decline of $\mathrm{O}_{2}{ }^{-}$ production by neutrophils in neonates anaesthetized with halothane and $\mathrm{N}_{2} \mathrm{O}$. Although the clinical importance of the current study remains to be determined, since only one neonate suffered from a postoperative wound infection, the perioperative susceptibility of neonates to bacterial infection may be partly attributed to the inhibition of $\mathrm{O}_{2}{ }^{-}$production by surgery and general anaesthesia. Further studies are required to substantiate this hypothesis.

\section{References}

1 Dale $M M$. The neutrophil leucocyte. In: Dale MM, Foreman JC (Eds.). Textbook of Immunopharmacology. Oxford: Blackwell, 1989; 37-55.

2 Curnutte JT, Whitten DM, Babior BM. Defective superoxide production by granulocytes from patients with chronic granulomatous disease. N Engl J Med 1974; 290 : 593-7.

3 Weiner-Kronish JP, Gropper MA, Matthay MA. The adult respiratory distress syndrome: definition and prognosis, pathogenesis and treatment. $\mathrm{Br} \mathrm{J}$ Anaesth 1990; 65: 107-29.

4 Lamy $M$, Deby-Dupont $G$, Deby $C$, et al. Measurements of mediator cascades during adult respiratory distress syndrome. In: Artigas A, Lemaire F, Suter PM, Zapol WM (Eds.). Adult Respiratory Distress Syndrome. New York: Churchill Livingstone, 1992, 71-88.

5 Bruce $D L$, Kahan BD. Effect of anesthesia and surgery on immunity. In: Mathieu A, Kahan BD (Eds.). Immunologic Aspects of Anesthetic and Surgical Practice. New York: Grune and Stratton, 1975; 171-82.

6 Espanol T, Todd GB, Soothill JF. The effect of anaesthesia on the lymphocyte response to phytohaemaglutinin. Clin Exp Immunol 1974; 18: 73-9.

7 Lee $Y$-TN. Effect of anesthesia and surgery on immunity. J Surg Oncol 1977; 9: 425-30.

8 Nakagawara M, Takeshige K, Takamatsu J, Takahashi S, Yoshitake J, Minakami S. Inhibition of superoxide production and $\mathrm{Ca}^{2+}$ mobilization in human neutrophils 
by halothane, enflurane, and isoflurane. Anesthesiology 1986; 64: 4-12.

9 Mikawa K, Maekawa N, Goto R, Yaku H, Obara H: Perioperative complement activation in neonates under halothane or fentanyl anaesthesia. Acta Anaesthesiol Scand 1992; 36: 469-73.

10 Mikawa K, Maekawa N, Ikegaki J, Goto R, Yaku H, Obara $H$. Perioperative changes in plasma $\mathrm{C} 3 \mathrm{a}$ and $\mathrm{CSa}$ concentrations in infants. Paediatric Anaesthesia 1992; 2: 123-31.

11 Nakamura H, Uetani Y, Komura M, Takada AS, Sano K, Matsuo T. Inhibitory action of bilirubin on superoxide production by polymorphonuclear leukocytes. Biol Neonate 1987; 52: 273-8.

12 Kugo M, Sano K, Uetani Y, Nakamura H. Superoxide dismutase in polymorphonuclear leukocytes of term newborn infants and very low birth weight infants. Pediatr Res 1989; 26: 227-31.

13 Holl JW. Anesthesia for gastrointestinal and abdominal wall disorders. In: Gregory GA (Ed.). Pediatric Anesthesia. 2nd ed. New York: Churchill Livingstone, 1992, 993-1014.

14 MacDonald NJ, Fitzpatrick GJ, Moore KP, Wren WS, Keenan $M$. Anaesthesia for congenital hypertyrophic pyloric stenosis: a review of 350 patients. Br J Anaesth 1987; 59: 672-7.

15 Obara H, Sugiyama D, Maekawa N, et al. Plasma cortisol levels in paediatric anaesthesia. Can Anaesth Soc J 1984; 31: 24-7.

16 Obara H, Maekawa N, Hoshina H, et al. Plasma levels of vitamin $E$ and lipoperoxide during paediatric anaesthesia. Can Anaesth Soc J 1985; 32: 358-63.

17 Sharonov BP, Govorova NJu, Lyzlova SN. A comparative study of serum proteins ability to scavenge active oxygen species: $\mathrm{O}_{2}{ }^{-}$and $\mathrm{OCI}^{-}$. Biochem Int 1988; 17: 783-90.

18 Ronser B. Fundamentals of Biostatistics. 3rd ed. Boston: PWS-KENT Publishing Company, 1990, 186-247.

19 Furukawa T, Tango T. Statistics for Medicine (authors' translation). Tokyo: Asakura, 1983, 170-92.

20 Sumimoto H, Takeshige K, Minakami S. Superoxide production of neutrophils. In: Kondo M, Oyanagi Y, Yoshikawa T (Eds.). Free Radicals in Clinical Medicine Vol. 1. Tokyo: Nihon Igakukan, 1987, 15-23.

21 Rossi $\mathrm{F}$. The $\mathrm{O}_{2}^{-}$-forming NADPH oxidase of the phagocytes: nature, mechanisms of activation and function. Biochim Biophys Acta 1986; 853: 65-89.

22 Matsuoka T. A sedative effect of dopamine on the respiratory burst in neonatal polymorphonuclear leukocytes. Pediatr Res 1990; 28: 24-7.

23 Busse $W W$, Sosman JM. Isoproterenol inhibition of isolated human neutrophil function. J Allergy Glin Immunol 1984; 73: 404-10.

24 Morley J, Hanson JM, Rumjanek VM. Lymphokines. In:
Dale MM, Foreman JC (Eds.). Textbook of Immunopharmacology. Oxford: Blackwell, 1989, 168-80.

25 Webster RO, Hong SR, Johnston RB Jr, Henson PM. Biological effects of the human complement fragments $\mathrm{CSa}$ and $\mathrm{C}^{\mathrm{d}} \mathrm{a}_{\mathrm{des}} \mathrm{Arg}$ on neutrophil function. Immunopharmacology 1980; 2: 201-19.

26 Tonnesen E, Brinkløv MM, Christensen NJ, Olesen AS, Madsen T. Natural killer cell activity and lymphoscyte function during and after coronary artery bypass grafting in relation to the endocrine stress response. Anesthesiology 1987; 67: 526-33.

27 Weissman $C$. The metabolic response to stress: an overview and update. Anesthesiology 1990; 73: 308-27.

28 Walton $B$. Effects of anaesthesia and surgery on immune status. Br J Anaesth 1979; 51: 37-43.

29 Wilson $C B$. Immunologic basis for increased susceptibility of the neonate to infection. J Pediatr 1986; 108: 1-12.

30 Hill $H R$. Biochemical, structural, and functional abnormalities of polymorphonuclear leukocytes in the neonate. Pediatr Res 1987; 375-82.

31 Beutow KC, Klein SW, Lane RB. Septicemia in premature infants: the characteristics, treatment, and prevention of septicemia in premature infants. Am J Dis Child 1965; 110: 29-41.

32 Gardner $P$, Carles $D G$. Infections acquired in a pediatric hospital. J Pediatrics 1972; 81: 1205-10. 